\title{
REVIEW
}

\section{Rethinking growth factors: the case of BMP9 during vessel maturation}

\author{
Ferran Medina-Jover1,2,3, Antoni Riera-Mestre ${ }^{4,5,6}$ and Francesc Viñals (101,2,3 \\ 1Program Against Cancer Therapeutic Resistance (ProCURE), Institut Català d'Oncologia, Hospital Duran i Reynals, L'Hospitalet de Llobregat, \\ Barcelona, Spain \\ 2Molecular Mechanisms and Experimental Therapy in Oncology Program (Oncobell), Institut d'Investigació Biomèdica de Bellvitge (IDIBELL), L'Hospitalet \\ de Llobregat, Barcelona, Spain \\ ${ }^{3}$ Departament de Ciències Fisiològiques, Facultat de Medicina i Ciències de la Salut (Campus de Bellvitge), Universitat de Barcelona, L'Hospitalet de \\ Llobregat, Barcelona, Spain \\ ${ }^{4}$ Hereditary Hemorrhagic Telangiectasia Unit, Internal Medicine Department, Hospital Universitari de Bellvitge, L'Hospitalet de Llobregat, Barcelona, Spain \\ 5Institut d'Investigació Biomèdica de Bellvitge (IDIBELL), L'Hospitalet de Llobregat, Barcelona, Spain \\ ${ }^{6}$ Faculty of Medicine and Health Sciences, Universitat de Barcelona, L'Hospitalet de Llobregat, Barcelona, Spain
}

Correspondence should be addressed to F Medina-Jover or F Viñals: ferranmedinajover@ub.edu or fvinyals@iconcologia.net

\begin{abstract}
Angiogenesis is an essential process for correct development and physiology. This mechanism is tightly regulated by many signals that activate several pathways, which are constantly interacting with each other. There is mounting evidence that BMP9/ALK1 pathway is essential for a correct vessel maturation. Alterations in this pathway lead to the development of hereditary haemorrhagic telangiectasias. However, little was known about the BMP9 signalling cascade until the last years. Recent reports have shown that while BMP9 arrests cell cycle, it promotes the activation of anabolic pathways to enhance endothelial maturation. In light of this evidence, a new criterion for the classification of cytokines is proposed here, based on the physiological objective of the activation of anabolic routes. Whether this activation by a growth factor is needed to sustain mitosis or to promote a specific function such as matrix formation is a critical characteristic that needs to be considered to classify growth factors. Hence, the state-of-the-art of BMP9/ ALK1 signalling is reviewed here, as well as its implications in normal and pathogenic angiogenesis.
\end{abstract}

\section{Introduction}

Vessel formation is essential for the transport of oxygen and nutrients to the tissues, and for the removal of waste substances. Several mechanisms of vessel formation have been described in normal and pathological conditions depending on the physiological context. However, sprouting angiogenesis is the most studied and relevant type (1).

Angiogenesis is defined as the formation of new vessels from preexisting ones (2). It is a multistep process that can be grouped into four different phases: initiation, proliferation, maturation, and quiescence. Angiogenesis is initiated by the selection of a tip cell that leads to the formation of the new vascular sprout. This cell is highly mobile and polarized, and it is characterized by several filopodia, which sense different signals that indicate the direction of the migration. Behind the tip cell, there are several stalk cells that support the elongation of the new vessel by an active proliferation, which contributes to

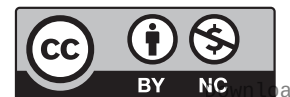

This work is licensed under a Creative Commons Attribution-NonCommercial 4.0 International License. 
the lumen formation of the vessel (3). The stalk cells that progressively get more distant from the tip cell, start a gradual phenotypical transformation. These maturating cells enter to cell-cycle arrest and, at the same time, keep an active metabolism to synthetize new matrix and cell contacts, among others, contributing to the consolidation and maturation of the newly formed vessel. When the maturating phase is complete and the vessel is fully formed and functional, the endothelial cells receive the name of quiescent cells (4).

Sprouting angiogenesis is a tightly regulated process controlled by several cytokines. These cytokines can compete or collaborate, resulting in a mixed effect, for instance, in the tip cell selection $(5,6)$. Classically, these cytokines are classified as angiogenic initiators or angiogenic maturating factors. Angiogenic signals such as hypoxia, vascular endothelial growth factor (VEGF), or fibroblast growth factor 2 (FGF-2) promote matrix degradation, tip cell formation, and proliferation (7). Maturating factors such as Notch, bone morphogenetic protein 9 (BMP9), or transforming growth factor $\beta$ (TGF$\beta)$ promote cell cycle arrest, formation of cell-cell contacts, pericytes recruitment, and matrix formation (8). As a general principle, growth factors have been associated with cell division. However, some of them can maintain an active metabolism to promote several functions regardless of cell division, being the case of BMP9. Therefore, a distinction between mitogenic factors and growth factors must be made. On the other hand, these growth factors could present a synergistic effect with mitogens (e.g. insulin) or an antagonistic effect by blocking cell division (e.g. BMP9).

Since the discovery of Activin receptor-like kinase 1 (ALK1) as the BMP9 highly affinity receptor (9), BMP9/ALK1 signalling has attracted interest. Here, the state-of-the-art of the BMP9 role in angiogenesis is reviewed, providing a new perspective on its activity as a growth factor.

\section{BMP9/ALK1 signalling cascade}

BMP9, also known as growth differentiation factor 2 (GDF2 ), is a cytokine of the TGF- $\beta$ superfamily. It is mainly produced in the liver as a proprotein that is cleaved before its secretion (10). BMP9 participates in several processes, including angiogenesis as a maturating factor (11). Acting as a homodimer, it binds to its high-affinity receptor ALK1 (9), which is expressed mainly in the endothelium (12). BMP10 is a closely BMP9-related cytokine with which it shares $65 \%$ of the aminoacidic identity (9). It is also synthetized as a proprotein and acts as a homodimer to activate $\operatorname{ALK} 1(9,13)$. However, BMP10 is produced in the right atria (13) and participates in cardiac development (14). Despite this, recent studies have shown that both BMPs have redundant roles in vessel maturation $(15,16)$. In addition, it has been described that an heterodimer formed by BMP9 and BMP10 could be responsible for the major BMP activity in endothelial cells (17). Nevertheless, the heterodimer structure has not been characterized yet, requiring further investigation (18).

Other BMPs also have a role in the regulation of vessel formation. BMP4/ALK3 signalling has been reported to be essential to vessel remodelling during the development of the circulatory system in mice $(19,20)$. BMP2/ALK3 signalling has a role in angiogenesis initiation or in chemotaxis promotion, depending on the cell model used $(21,22,23)$. Moreover, a study has recently proven that BMP6 binds to ALK2 and promotes vessel formation by regulating the Hippo pathway, which can modulate VEGF and Notch signalling (24).

BMPs bind to a tetrameric signalling complex formed by two homodimers, one of bone morphogenetic protein receptor 1 (BMPRI) (ALK1-3, ALK6) and one of BMPRII (BMPRII Activin receptor IIA (ActRIIA) or ActRIIB) (25, 26). Moreover, to activate downstream messengers, a coreceptor might be needed, and depending on the complexity, different coreceptors might intervene (27). For example, in order to start its signalling cascade, ALK1 could be modulated by the presence of its coreceptor, endoglin (28). Therefore, the signalling complex is composed of two subunits of BMPRI, two subunits of BMPRII, and two subunits of the coreceptor.

The presence of the ligand increases the formation and stabilization of the receptor signalling complex (27). The BMPRII serine/threonine activity is constitutively active, and once the oligomer is formed, it phosphorylates the BMPRI receptor, which is a critical step in this signal transduction mechanism (29). Upon phosphorylation, BMPRI can activate receptor-regulated small mothers against decapentaplegic (R-SMAD) proteins (30). To act as transcription factors, R-SMADs need to form a heterotrimer structure, which is composed of two R-SMAD and one SMAD-4. When the trimer is formed, it can translocate to the nucleus and regulate gene expression. In the case of BMP9, it can activate SMADs $1 / 5 / 8$, which promote the expression of different genes such as inhibitor of DNA binding 1 (ID1), endoglin $(E N G)$, or Transmembrane Protein 100 (TMEM100) $(31,32,33)$.

However, there is still another level of complexity regarding the regulation of this cascade. Other SMADs

This work is licensed under a Creative Commons Attribution-NonCommercial 4.0 International License. 
such as SMAD-6 and -7 act as inhibitors of R-SMADs (34) by competing for SMAD-4 (35). In addition, some members of the TGF- $\beta$ family have been described to activate other effectors excluding SMAD signalling. For instance, it is known that TGF- $\beta$ can activate TGF- $\beta$ activated kinase 1 (TAK-1) independently of SMADs $(36,37)$. Despite this, little is known about non-canonical signalling in BMPs, which has only been described in bone. In osteoblasts, other members of the BMP family, such as BMP2 and 7 (38), regulate different processes like osteogenesis $(36,39$, 40). Nonetheless, SMAD-independent signalling has not been described to be directed by the BMP9 cascade in the endothelium.

\section{Regulation of vessel maturation by BMP9}

Inducing vessel maturation is a key step of the angiogenic process. It involves several processes such as cell cycle arrest, new matrix formation, reestablishment of cell junctions, blood flow, and pericyte recruitment (Fig. 1). All these elements are essential to produce a functional vessel. Therefore, the role of BMP9/ALK1 signalling in each of them will be further discussed.

\section{Proliferation arrest}

Proliferation can be induced by different pathways and needs the activation of several mechanisms related to DNA replication and protein production, among others. However, the blockage of only a few key elements is enough to stop cell division. For instance, TGF- $\beta$ blocks proliferation by inhibiting cycle-dependent kinases, which directly regulate cell cycle (41). Instead, BMP9 downregulates upstream signalling cascades. In endothelium, two major pathways have been described to be involved in enhancing proliferation during angiogenesis: the phosphoinositol 3 kinase (PI3K)/Rac-alpha serine/threonine protein kinase (AKT) pathway and the (mitogen-activated protein kinase (MAPK)/extracellular signal-regulated kinase (ERK) pathway.

On one hand, PI3Ks are a family of lipid kinases that catalyse the production of phosphatidylinositol trisphosphates that activate several effectors. The most widely expressed PI3Ks in endothelium are class I PI3Ks, and especially the catalytic subunit p110 $\alpha$ (42), which is key for the regulation of endothelial migration (43). When activated, class I PI3Ks can rapidly activate AKT. AKT is a well-known kinase that can regulate survival, cell metabolism, and protein synthesis, among others (44).
AKT can activate mammalian target of rapamycin complex 1 (mTORC1), a complex that promotes protein synthesis via the direct activation of p-70-S6 kinase (S6K), which in turn activates the ribosomal protein S6 (S6) subunit of the ribosome (45). Moreover, mTORC1 promotes other anabolic pathways, enhancing de novo lipid synthesis. In addition, AKT downregulates forkhead box O (FOXO) transcription factors. These factors, especially FOXO1 in endothelium, promote cell cycle arrest by downregulating c-Myc signalling and produce a metabolic switch by reducing glycolysis and respiration $(46,47)$.

Some studies have shown that BMP9 is responsible for downregulating PI3K/AKT signalling and that it can reverse vascular endothelial growth factor (VEGF) effects $(48,49)$. PI3K signalling was found to be upregulated in patient samples with mutations in ALK1 or endoglin, and in in vivo and in vitro ALK1-defective mice models, increasing endothelial cell proliferation and causing aberrant vessel growth. These effects were reverted when PI3K inhibitors were administered both in vivo and in vitro. Physiologically, PI3K inhibition is regulated by BMP9 signalling. ALK1/ BMP9 can induce the expression of phosphatase and tensin homolog (PTEN), a phosphatase that dephosphorylates phosphatidylinositol-3,4,5-triphosphate (PIP3), inhibiting the PI3K/AKT axis and, as a consequence, negatively regulating endothelial cell proliferation (50).

On the other hand, MAPK is found in a highly conserved group of pathways that are activated by many cytokines. The most studied one is the MAPK/ERK pathway, which is involved in proliferation (51). It is composed of three different effectors: rapidly accelerated fibrosarcoma kinase, mitogen-activated protein kinase kinase, and ERK $1 / 2$. When phosphorylated, ERK is translocated to the nucleus, where it activates several cellular programmes related to protein synthesis and proliferation (52), among others. For a long time, it has been established that this pathway is activated in endothelial cells by angiogenic initiators such as VEGF. BMP9 has been shown to downregulate ERK activation in a transcriptiondependent manner. Hence, using SMAD1/5/8, BMP9/ ALK1 can induce serum and glucocorticoid activated kinase 1 (SGK1) expression (53), and through a not yet described mechanism, this kinase downregulates ERK activation (54). SGK1 is one of the three members of the serum glucocorticoid kinases, which forms part of the AGC family of serine/threonine protein kinases (55). Distinctly from other SGKs, SGK1 is tightly regulated at both transcriptional and posttranscriptional levels (56), and its half-life is estimated to be around $30 \mathrm{~min}$ long (57). Besides regulating proliferation, SGK1 has been described

This work is licensed under a Creative Commons Attribution-NonCommercial 4.0 International License. 

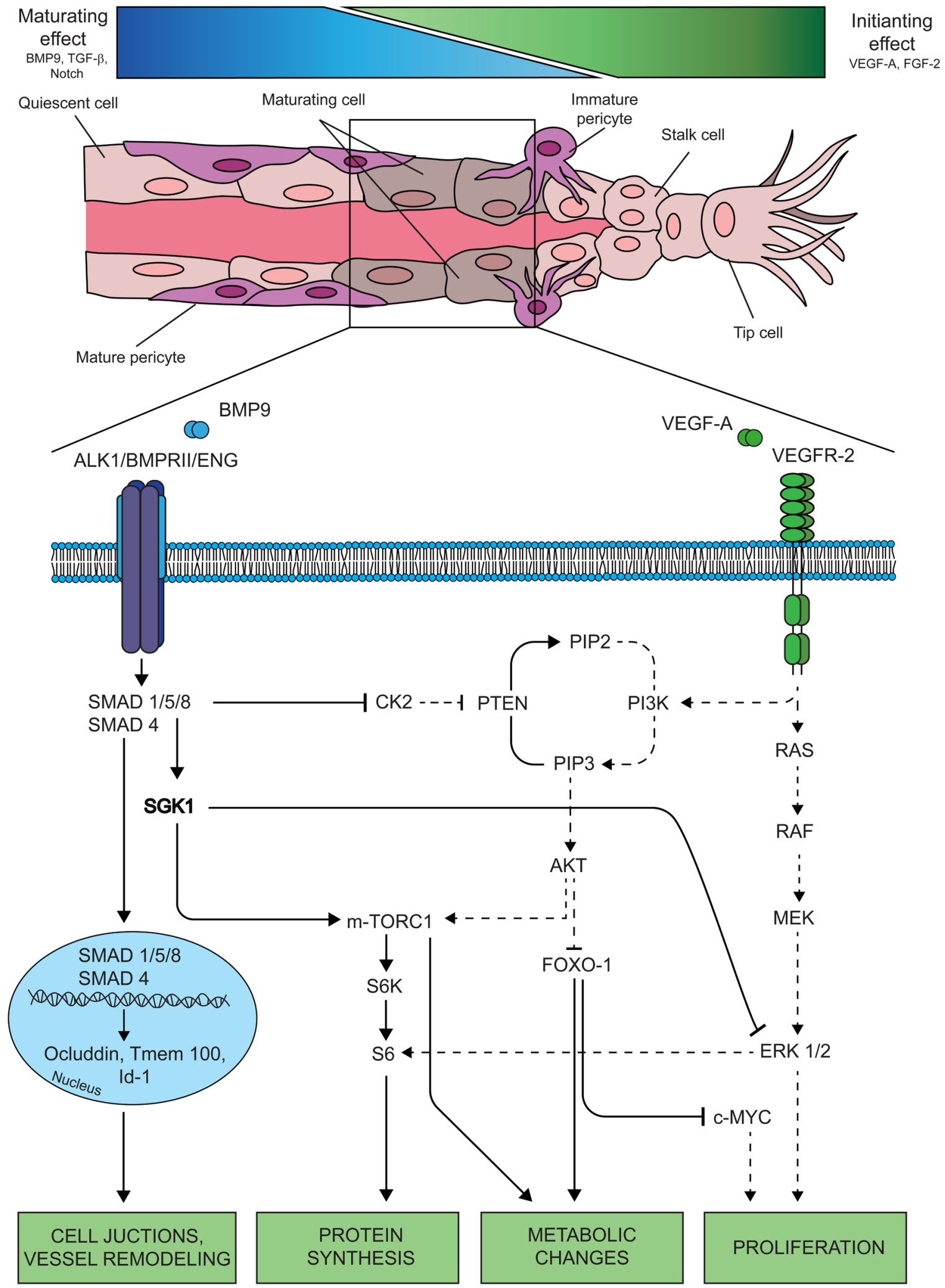

\section{Figure 1}

Schematic illustration of the maturating phase of angiogenesis. For clarity purposes not all relations are shown. Segmented arrows represent signalling pathways downregulated by BMP9/ALK1 axis. 
to be involved in other hallmarks of the maturation process that will be discussed below, proving its relevance as a signalling hub that vehiculates the effects of BMP9 signalling in endothelium.

However, some works have described that BMP9 has a proangiogenic effect, increasing cell number and the number of sprouts. Interestingly, both works use endothelial cells derived from stem cells and use low doses and long-term incubations $(58,59)$. Further research is needed in order to fully elucidate if this proangiogenic effect is due to long-term exposure to BMP9, or a dosedependent biphasic effect on endothelial cells.

\section{Extracellular matrix, cell-cell contacts, and protein synthesis}

In the first step of angiogenesis, matrix and cell-cell junctional components are degraded in order to allow migration. However, in the maturating phase, the reconstitution of these structures is needed and, in order to produce them, protein synthesis must be highly active. BMP9 has a role in this process by contributing to the arrest of VEGF-induced vascular endothelial cadherin (VE-Cadherin) degradation, thus stabilizing adherent junctions (60). BMP9 also promotes the synthesis of proteins involved in cell-cell junctions such as occludin (60). In other cell types like fibroblasts, BMP9 can increase the production of matrix components (61), and its role as a key regulator of fibrosis is under discussion (62). In endothelial cells, by upregulating SGK1, BMP9 promotes the activation of mTORC1/S6K/S6 axis, which results in an increase in protein synthesis (54). The increase of SGK1 expression is essential for vessel correct development. SGK1 KO mouse is embryonic lethal due to angiogenic defects and cardiovascular malformations (63). Closely related to AKT (64), it has been described that SGK1 can be activated, at least partially, when AKT is inhibited and activate the same effectors as AKT (64, $65,66,67,68)$. Therefore, SGK1 allows cell proliferation blockade while maintaining an active metabolism. The use of these alternative pathways that promote cell growth but block proliferation at the same time has been recurrently reported to happen in different physiological processes in which cell division is counterproductive. It has been assumed that cell growth and division act in parallel. Nevertheless, some factors such as BMP9 act as antimitogenic and, at the same time, promote cell growth. These implications will be further discussed below, and also why the concept of growth factor should be re-evaluated.

\section{The role of metabolism}

It should come as no surprise that a cell phenotype change from a proliferative to a maturating one is accompanied by metabolic changes. In the last years, endothelium metabolism has attracted increased attention, and some groups have tried to characterize the endothelial metabolism in the different stages of the angiogenic process. Tip cell, stalk cell, and quiescent endothelial cell metabolism are indeed well characterized, and reviewed elsewhere $(69,70,71)$, but little is known about the metabolism of a maturating endothelial cell. This metabolism might be supposed to be a transition from a highly glycolytic VEGF-influenced metabolism (72) to a reactive oxygen species-protective metabolism derived by the influence of Notch pathway (73). However, some evidence supports the hypothesis that BMP9 could have a role in regulating endothelial cell metabolism. Several reports link BMP9 to the regulation of glucose metabolism, reduction of gluconeogenesis in liver (74), and the reduction of glucose blood levels also in liver $(75,76)$. In endothelium, hyperglycaemia has been reported to downregulate ALK1 signalling (60) and AMP-activated protein kinase (AMPK), a protein that is well-known for sensing the energy state of the cell, to inhibit SMAD 1/5/8 phosphorylation by BMP9/ ALK1 axis (77). Moreover, BMP9 activates mTORC1, also well known for its role in regulating metabolism $(45,78$, $79)$ and for its crosstalk with AMPK $(80,81,82)$, in an SGK1dependent manner.

\section{Blood flow and shear stress}

Biomechanical forces also have a role in BMP9/ALK1 signalling. Endothelium is directly exposed to blood flow that produces a frictional force, parallel to the flow, in the surface of the endothelium. This force is associated with shear stress, which depends on the structure of the vessel, blood viscosity, and velocity (83). Therefore, shear stress is used by endothelial cells as a signal, and different blood flow regimes can induce the expression of different genes (84, $85)$. Thus, shear stress contributes to regulate endothelial identity, vascular development, and remodelling (86).

Regarding BMP9, ALK1 signalling cascade have been put forward to be induced by an increase of fluid flow (87) and by oscillatory shear stress, independently of ligand (88). Shear stress increases endoglin-ALK1 interaction by strengthening BMP9 affinity to ALK1 and reducing its EC50 (89). Therefore, loss of blood flow would reduce ALK1 activation, and therefore vessel maturation would not be completed, enhancing the appearance of arteriovenous

This work is licensed under a Creative Commons Attribution-NonCommercial 4.0 International License. 
malformations (90). Interestingly, endoglin has been described as critical mediator between sensing blood flow (91) and ALK1 signalling (92).

\section{Mural cell recruitment}

Mural cells coat endothelial cells and help to establish the newly formed vessel. Depending on their location, mural cells differ. In capillaries, where angiogenesis take place, pericytes are the predominant type of mural cells (93). Several cytokines such as platelet-derived growth factor (PDGF), sphingosine 1 phosphate (S1P), and angiotensin (ANG)/TEK Receptor Tyrosine Kinase 2 (Tie2) are involved in pericyte attraction and blood vessel maturation (94). Depending on the stage of the angiogenic process, pericytes adopt an immature phenotype in the sprouting front and a mature phenotype in the maturating plexus. This phenotype is accompanied by different molecular traits that regulate shape or proliferation, among others (95).

The continuous crosstalk between pericytes and endothelium is necessary to form a functional vessel $(94,96$, 97). The TGF- $\beta$ family is involved in pericyte differentiation. The activation of ALK5 in mesenchymal cells promotes its differentiation $(98,99,100)$. ALK1 has been reported to be able to downregulate ALK5 in endothelium by directly inhibiting SMAD 2/3 phosphorylation (100) and therefore, influencing the mural recruitment. However, other evidences suggest that, for a proper signalling, ALK1 needs to form a complex with ALK5 (100).

\section{Crosstalk with other maturating cytokines}

As mentioned above, the interplay between different cytokines is critical in order to develop a functional vessel. Here the crosstalk of BMP9 with other well-known maturating cytokines will be reviewed.

\section{Crosstalk between TGF- $\beta$ family members}

TGF- $\beta$ and BMP9 are both maturating cytokines of the TGF- $\beta$ family. For a long time, both of them were assumed to have the same effect on angiogenesis. However, it is not the case. TGF- $\beta$ signals through ALK5 and activates SMAD 2/3, while BMP9 uses ALK1 and activates SMAD 1/5/8 (101), stimulating different gene expression patterns (102). Moreover, some works have reported that the inhibition of BMP9/10 directly produces arteriovenous malformations (AVM) in vivo $(48,103)$. Interestingly, the specific endothelial knockout of SMAD 2/3 produces incomplete vessel maturation and mural cell recruitment (104). Therefore, TGF- $\beta$ is not capable of substituting the BMP9 function and vice versa.

Some studies have suggested that ALK1 can inhibit ALK5 signalling pathway (99). Others have observed that the disruption of intermediate steps in this crosstalk conducts to overactivation of ALK5 (105). In addition, BMP9 has been described to be able to enhance TGF$\beta$ expression in endothelium (106). This has led to the assumption that for proper maturation, both pathways need to be in balance (99).

\section{Crosstalk with Notch signalling}

Notch pathway is an essential regulator of cell differentiation. This pathway is based on the interaction of adjacent cells, where one of them carries the ligand and the other one bears the receptor. When this pathway is activated, the intracellular domain of the receptor is proteolyzed and translocated to the nucleus, where it acts as a transcription factor (107). In the angiogenic process, it regulates tip cell selection and maturation. Depending on the localization and the ligand, the Notch pathway might have different effects $(108,109)$ whereas Notch-Delta Like Canonical Notch Ligand 4 (Dll4) enhances maturation, Notch-Jagged1 activates initiation.

Notch signalling has been involved in the formation of AVM (110, 111), and in cell-cycle arrest (112), which has been proven to be essential in vessel differentiation (113). Some works have studied the crosstalk between BMP9 and Notch. They have stablished that, through SMAD 1/5/8, BMP9 can promote the expression of Hairy/ enhancer-of-split related with YRPW motif protein 1 (HEY1)/HEY2 and hairy and enhancer-of-split (HES) $(114,115)$, the canonical targets of Notch, which have a critical role in vessel development (116). In addition, HEY1 has been described as a p53 upregulator, which arrests proliferation $(117,118,119)$. Moreover, it has also been reported that Notch-D1l4 can interact with SMAD $1 / 5$, enhancing their activity and their expression (120, 121). Another work depicts that both Notch-Dll4 and BMP9 signalling are interdependent (106). However, other works claim the opposite, suggesting that the interaction between Notch and SMADs is not synergic, whereas they show evidences of a downregulatory crosstalk (122). These differences can be explained by the ligand that is contributing to this response, as it has been mentioned above. 


\section{Crosstalk with Angiopoietins}

Angiopoietin 1 (Ang1) is another key maturating factor. It interacts with Tie 2 receptor and promotes vascular stabilization. In addition, some studies have proven that Ang1 is capable of promoting a signalling cascade using integrins $(123,124,125)$. Transgenic mice with Ang1 deficiencies are embryonic lethal and present defects on the endothelial extracellular matrix (126). Angiopoietin 1 functions in vasculature are wide, but they are mostly directed to the promotion of quiescence and cell survival (127). For instance, they do it by enhancing Notch-Dll4 signalling (128), although some of these aspects are controversial and discussed elsewhere (129). Even though a crosstalk between BMP9 and Ang1 would be of great interest if unravelled, until now, only one study has suggested a possible interaction between Ang1 and the TGF- $\beta$ family. Therefore, further investigation is still required on this matter (130).

Regarding angiopoietin 2, some works have described an implication in the ALK1/SMAD signalling pathway. Reduced levels of Ang2 in blood were suggested as a biomarker for facilitating the diagnosis of possible HHT patients (131), a disease produced by mutations in ALK1 signalling pathway. However, other works describe that SMAD4 is a repressor of the Ang2 gene. Thus, the loss of SMAD4 increased the levels of expression of Ang2, which induced arteriovenous malformations. The in vivo inhibition of Ang2 in SMAD4 endothelial KO mice restored the original phenotype (132).

\section{When ALK1/BMP9 signalling is disrupted HHT}

Since many years ago, it is a well known fact that mutations that affect the ALK1 signalling cascade produce abnormal growth and wrong maturation of vessels in animals models (reviewed elsewhere $(26,133,134)$ ) and in patients (135). This disease, known as hereditary haemorrhagic telangiectasia (HHT) or Rendu-Olser-Weber syndrome (ORPHA774), highlights the importance of BMP9/ALK1 in the regulation of maturation.

HHT is a rare autosomal dominant vascular disease characterized by telangiectases and larger vascular malformations (VMs) (136). The hallmark of HHT is telangiectasis, which is an abnormal communication between an arteriole and a dilated and tortuous venule in the capillary bed. HHT can be diagnosed either through molecular genetic test or using the Curaçao clinical criteria (recurrent epistaxis, cutaneous/mucosal telangiectasia, visceral VMs, and a first-degree family member with HHT) $(137,138)$. Therapeutic strategies aim at reducing potential complications caused by VMs, but there is currently no curative treatment for HHT.

Mutations in the endoglin $(E N G)$ and activin A receptorlike type 1 (ACVRL1) genes are detected in approximately $90 \%$ of cases submitted for molecular diagnosis and cause HHT1 and HHT2, respectively $(137,139)$. ACVRL1 gene encodes for ALK1 and ENG gene encodes for endoglin $(139,140)$. Although ALK1 and endoglin are components of the same BMP9 receptor complex, pathogenic variants in their genes are related to different clinical phenotypes. Pulmonary arteriovenous malformations (AVMs) and brain VMs are more common in patients with HHT1, while hepatic VMs are more common in HHT2 (137). Other mutations have been described to affect the SMAD4 gene MADH4 in less than $2 \%$ and cause juvenile polyposis/ HHT overlap syndrome (8) (141) and even less frequently, in the BMP9 gene GDF2 (142), and one patient with a BMPR2 pathogenic variant and suspected HHT has been reported (143).

Despite the good knowledge of the clinical aspects of the disease, the molecular mechanisms underlying the pathology have not emerged until the publication of recent studies (144).

Although many HHT features have been elucidated, increasing understanding of HHT is vital for providing insights into molecular regulation of vascular development and improving the care of patients $(144,145)$. When ALK1/ BMP9 signalling is disrupted, the maturation process is affected, PI3K/AKT and MAPK/ERK pathways remain active, and therefore, endothelial cells keep proliferating in the AVMs $(48,49,146)$. In fact, it has been detected several intermediates of the PI3K/AKT signalling pathway on paraffin-embedded skin samples from patients with both HHT1 and HHT2 $(49,146)$.

These studies have opened the door to alternative treatments with PI3K inhibitors $(48,49,146)$ and SMAD $1 / 5 / 8$ activators (147). Moreover, casein kinase 2 (CK2) has also been proposed as a pharmacological target. CK2 is responsible for the inhibitory phosphorylation of PTEN. In normal conditions, SMAD4 can inhibit CK2 expression. However, in SMAD4 mutated models, CK2 remains activated. Therefore, upon pharmacologically inhibition of CK2, PTEN activity is restored and AVM formation is reduced (148). Alternatively, some studies have tried other ways to reproduce the impairing effect in VEGF signalling that in physiological conditions is performed by BMP9. The use of VEGF inhibitors has been successful to some extent in HHT patients

This work is licensed under a Creative Commons Attribution-NonCommercial 4.0 International License. 
$(149,150,151,152,153)$. Furthermore, a recent study in mice reduced AVM formation using mTORC1 and VEGF inhibitors (103). Although more extensive clinical trials are needed, these promising therapies become the first opportunity to directly act in the source of the disease, that is, the vascular malformations.

\section{Redefining growth factors keeping the purpose in mind}

In the present article, the effect of several cytokines in endothelial maturation has been reviewed. The use of common pathways by initiating (e.g. VEGF) and maturating factors (e.g. BMP9) has followed a recurrent pattern regarding some events during angiogenesis. For instance, the activation of mTORC1/S6K/S6 axis is used by both initiating and maturating factors, although by different pathways: PI3K-AKT for mitogenic growth factors (e.g. VEGF) or by SGK1 for antimitogenic growth factor (e.g. BMP9). This emphasizes that initiating and maturating factors are not opposite to each other but rather complementary. As a general principle, growth factors have been assumed to promote proliferation and, so as to maintain cell division, they must activate several anabolic pathways, such as protein and nucleotide synthesis. However, some growth factors can induce the activation of these pathways and still not promote cell division. Therefore, growth factors should be classified as mitogenic or non-mitogenic. One example of these factors is the nerve growth factor (NGF), which although activates the ERK signalling, indeed promotes differentiation instead of proliferation through the activation of cAMP response element binding (CREB) in nervous cell types $(154,155)$. Considering this, another aspect of growth factor biology that is essential for their classification is proposed here, which is a distinction between growth factors that actively act as antimitogenic, and those neutral non-mitogenic factors that neither block proliferation nor promote it. Antimitogenic factors must activate alternative routes in order to maintain cellular growth or differentiation and at the same time inhibit cell division. For instance, Notch blocks proliferation in endothelial cells while it promotes arterial differentiation and vessel stabilization (156). Besides, neutral non-mitogenic growth factors can act synergistically with mitogenic factors to boost proliferation. A paradigmatic case for that is insulin, which promotes many anabolic routes such as glycogenesis and lipogenesis in several cell types. Moreover, insulin does not always promote proliferation (157), in fact, in some cell types, the blockade of the insulin receptor does not impair cell division, despite it impairs the metabolic effects mediated by insulin (158). Thus, neutral nonmitogenic growth factors can be used as a complement of a mitogenic growth factor to enhance proliferation by the overactivation of anabolic pathways, whereas they cannot activate cell division alone. In brief, growth factors should be differentiated by keeping the objective of the activation of these pathways in mind. From mitogenic growth factors, which use these anabolic pathways to maintain replication, to growth factors that activate these mechanisms to promote a specific function, such as differentiation, maturation, or nutrient storage.

Therefore, in the context of angiogenesis, mitogenic growth factors, such as VEGF, and antimitogenic growth factors, such as BMP9, should be distinguished. As it has been exposed, VEGF uses anabolic pathways, such mTORC1/S6, as a platform to sustain mitosis. On the other hand, BMP9 activates alternative routes in order to maintain the mTORC/S6 axis active, while in turn inhibiting cell proliferation.

\section{Concluding remarks}

Angiogenesis is a complex and dynamic process. It is regulated by many cytokines with, sometimes, still not well-understood effects. BMP9 has a critical role in endothelium maturation, enhancing cell cycle arrest and promoting cell-cell contacts and protein synthesis. From our perspective, several pieces of evidence such as the in vivo BMP9/BMP10 inhibition, support that the BMP9 effect cannot be replaced by TGF- $\beta$. Due to its remarkable complexity, more light needs to be shed on this matter so as to fully understand the whole process of angiogenesis. However, in the last years, some works have proposed a breakthrough perspective on the regulation of this mechanism, which gives some new alternative explanations to the topic and offers new therapeutic opportunities for HHT patients.

Taking endothelial maturation as an example, the concept of growth factor has been discussed here. Inducing cellular growth is not always accompanied by division. Cellular growth can have other purposes, for instance, to store nutrients or to form a proper cellular structure for the performance of a specific function. Thus, another classification of growth factors has been proposed here, based on the purpose of the activation of the anabolic pathways. Both non-mitogenic and mitogenic factors can use the same pathways because they all need anabolic routes

This work is licensed under a Creative Commons Attribution-NonCommercial 4.0 International License. 
to be activated. Nevertheless, their ultimate objectives are different, and so are their outcomes.

\section{Declaration of interest}

The authors declare that there is no conflict of interest that could be perceived as prejudicing the impartiality of this review.

\section{Funding}

This study was funded by the Ministerio de Ciencia, Innovación y Universidades (Spain), which is part of the Agencia Estatal de Investigación (AEI), through the project SAF2017-85869-R and PID2020-117815RB-I00 (co-funded by the European Regional Development Fund, ERDF, 'a way to build Europe') to F V, by the Instituto de Salud Carlos III, through the project PI20/00592 (also co-funded by European Regional Development Fund, ERDF, 'a way to build Europe') to A R M, and with the support to F V of the Departament de Recerca Universitats of the Generalitat de Catalunya (2017SGR449).

\section{Author contribution statement}

Writing of the manuscript: F M J, A R M, F V.

\section{Acknowledgements}

F M J was awarded with a FI-SDUR fellowship of the Agència de Gestió i Ajuts Universitaris i de Recerca which is a part of the Departament de Recerca i Universitats of the Generalitat de Catalunya. The authors thank the CERCA Program/Generalitat de Catalunya for their institutional support. F M J and F V C would like to thank Dr Ana Angulo Urarte for her interesting and constructive comments.

\section{References}

1 Carmeliet P. Mechanisms of angiogenesis and arteriogenesis. Nature Medicine 20006 389-395. (https://doi.org/10.1038/74651)

2 Potente M, Gerhardt H \& Carmeliet P. Basic and therapeutic aspects of angiogenesis. Cell 2011146 873-887. (https://doi.org/10.1016/j. cell.2011.08.039)

3 Carmeliet P \& Jain RK. Molecular mechanisms and clinical applications of angiogenesis. Nature 2011473 298-307. (https://doi. org/10.1038/nature10144)

4 Jain RK. Molecular regulation of vessel maturation. Nature Medicine 20039 685-693. (https://doi.org/10.1038/nm0603-685)

5 Siekmann AF \& Lawson ND. Notch signalling limits angiogenic cell behaviour in developing zebrafish arteries. Nature 2007445 781-784. (https://doi.org/10.1038/nature05577)

6 Pontes-Quero S, Fernández-Chacón M, Luo W, Lunella FF, CasqueroGarcia V, Garcia-Gonzalez I, Hermoso A, Rocha SF, Bansal M \& Benedito R. High mitogenic stimulation arrests angiogenesis. Nature Communications 201910 2016. (https://doi.org/10.1038/s41467-019. 09875-7)

7 Tian H, Huang JJ, Golzio C, Gao X, Hector-Greene M, Katsanis N \& Blobe GC. Endoglin interacts with VEGFR2 to promote angiogenesis. FASEB Journal 201832 2934-2949. (https://doi.org/10.1096/ fj.201700867RR)
8 García de Vinuesa A, Abdelilah-Seyfried S, Knaus P, Zwijsen A \& Bailly S. BMP signaling in vascular biology and dysfunction. Cytokine and Growth Factor Reviews 201627 65-79. (https://doi.org/10.1016/j. cytogfr.2015.12.005)

9 David L, Mallet C, Mazerbourg S, Feige JJ \& Bailly S. Identification of BMP9 and BMP10 as functional activators of the orphan activin receptor-like kinase 1 (ALK1) in endothelial cells. Blood 2007109 1953-1961. (https://doi.org/10.1182/blood-2006-07-034124)

10 Bidart M, Ricard N, Levet S, Samson M, Mallet C, David L, Subileau M, Tillet E, Feige JJ \& Bailly S. BMP9 is produced by hepatocytes and circulates mainly in an active mature form complexed to its prodomain. Cellular and Molecular Life Sciences 201269 313-324. (https://doi.org/10.1007/s00018-011-0751-1)

11 David L, Mallet C, Keramidas M, Lamandé N, Gasc JM, DupuisGirod S, Plauchu H, Feige JJ \& Bailly S. Bone morphogenetic protein-9 is a circulating vascular quiescence factor. Circulation Research 2008102 914-922. (https://doi.org/10.1161/ CIRCRESAHA.107.165530)

12 Seki T, Yun J \& Oh SP. Arterial endothelium-specific activin receptorlike kinase 1 expression suggests its role in arterialization and vascular remodeling. Circulation Research 200393 682-689. (https://doi. org/10.1161/01.RES.0000095246.40391.3B)

13 Neuhaus H, Rosen V \& Thies RS. Heart specific expression of mouse BMP-10 a novel member of the TGF- $\beta$ superfamily. Mechanisms of Development 199980 181-184. (https://doi.org/10.1016/s09254773(98)00221-4)

14 Chen H, Brady Ridgway J, Sai T, Lai J, Warming S, Chen H, RooseGirma M, Zhang G, Shou W \& Yan M. Context-dependent signaling defines roles of BMP9 and BMP10 in embryonic and postnatal development. PNAS 2013110 11887-11892. (https://doi.org/10.1073/ pnas.1306074110)

15 Ricard N, Ciais D, Levet S, Subileau M, Mallet C, Zimmers TA, Lee SJ, Bidart M, Feige JJ \& Bailly S. BMP9 and BMP10 are critical for postnatal retinal vascular remodeling. Blood 2012119 6162-6171. (https://doi. org/10.1182/blood-2012-01-407593)

16 Levet S, Ouarné M, Ciais D, Coutton C, Subileau M, Mallet C, Ricard N, Bidart M, Debillon T, Faravelli F, et al. BMP9 and BMP10 are necessary for proper closure of the ductus arteriosus. PNAS 2015112 E3207-E3215. (https://doi.org/10.1073/pnas.1508386112)

17 Tillet E, Ouarné M, Desroches-Castan A, Mallet C, Subileau M, Didier R, Lioutsko A, Belthier G, Feige JJ \& Bailly S. A heterodimer formed by bone morphogenetic protein 9 (BMP9) and BMP10 provides most BMP biological activity in plasma. Journal of Biological Chemistry 2018293 10963-10974. (https://doi.org/10.1074/jbc.RA118.002968)

18 Gipson GR, Goebel EJ, Hart KN, Kappes EC, Kattamuri C, McCoy JC \& Thompson TB. Structural perspective of BMP ligands and signaling Bone 2020140 115549. (https://doi.org/10.1016/j.bone.2020.115549)

19 Astorga J \& Carlsson P. Hedgehog induction of murine vasculogenesis is mediated by Foxf1 and Bmp4. Development 2007134 3753-3761. (https://doi.org/10.1242/dev.004432)

20 Park C, Lavine K, Mishina Y, Deng CX, Ornitz DM \& Choi K. Bone morphogenetic protein receptor $1 \mathrm{~A}$ signalling is despensable for hematopoietic development but essential for vessel and atrioventricular endocardial cushion formation. Development 2006 133 3473-3484. (https://doi.org/10.1242/dev.02499)

21 Raida M, Clement JH, Leek RD, Ameri K, Bicknell R, Niederwieser D $\&$ Harris AL. Bone morphogenetic protein 2 (BMP-2) and induction of tumor angiogenesis. Journal of Cancer Research and Clinical Oncology 2005131 741-750. (https://doi.org/10.1007/s00432-005-0024-1)

22 Langenfeld EM \& Langenfeld J. Bone morphogenetic protein-2 stimulates angiogenesis in developing tumors. Molecular Cancer Research 20042 141-149. (https://doi.org/10.1158/1541-7786.141.2.31)

23 Rothhammer T, Bataille F, Spruss T, Eissner G \& Bosserhoff AK. Functional implication of BMP4 expression on angiogenesis in malignant melanoma. Oncogene 200726 4158-4170. (https://doi. org/10.1038/sj.onc.1210182) 
24 Pulkkinen HH, et al. BMP6/TAZ-Hippo signaling modulates angiogenesis and endothelial cell response to VEGF. Angiogenesis 2020 13

25 Scharpfenecker M, van Dinther M, Liu Z, van Bezooijen RL, Zhao Q, Pukac L, Löwik CW \& ten Dijke P. BMP-9 signals via ALK1 and inhibits bFGF-induced endothelial cell proliferation and VEGF-stimulated angiogenesis. Journal of Cell Science 2007120 964-972. (https://doi. org/10.1242/jcs.002949)

26 Desroches-Castan A, Tillet E, Bouvard C \& Bailly S. BMP9 and BMP10: two close vascular quiescence partners that stand out. Developmental Dynamics 2022251 178-197. (https://doi.org/10.1002/DVDY.395)

27 Miyazono K, Kamiya Y \& Morikawa M. Bone morphogenetic protein receptors and signal transduction. Journal of Biochemistry 2010147 35-51. (https://doi.org/10.1093/jb/mvp148)

28 Guerrero-Esteo M, Sanchez-Elsner T, Letamendia A \& Bernabeu C. Extracellular and cytoplasmic domains of endoglin interact with the transforming growth factor-beta receptors I and II. Journal of Biological Chemistry 2002277 29197-29209. (https://doi.org/10.1074/jbc. M111991200)

29 Huse M, Chen YG, Massagué J \& Kuriyan J. Crystal structure of the cytoplasmic domain of the type I TGF $\beta$ receptor in complex with FKBP12. Cell 199996 425-436. (https://doi.org/10.1016/s00928674(00)80555-3)

30 Atri D, Larrivée B, Eichmann A \& Simons M. Endothelial signaling and the molecular basis of arteriovenous malformation. Cellular and Molecular Life Sciences 201371 867-883. (https://doi.org/10.1007/ s00018-013-1475-1)

31 Valdimarsdottir G, Goumans MJ, Rosendahl A, Brugman M, Itoh S, Lebrin F, Sideras P \& ten Dijke P. Stimulation of Id1 expression by bone morphogenetic protein is sufficient and necessary for bone morphogenetic protein-induced activation of endothelial cells. Circulation 2002106 2263-2270. (https://doi.org/10.1161/01. CIR.0000033830.36431.46)

32 Nolan-Stevaux O, Zhong W, Culp S, Shaffer K, Hoover J, Wickramasinghe D \& Ruefli-Brasse A. Endoglin requirement for BMP9 signaling in endothelial cells reveals new mechanism of action for selective anti-endoglin antibodies. PLoS ONE 20127 e50920. (https:// doi.org/10.1371/journal.pone.0050920)

33 Somekawa S, Imagawa K, Hayashi H, Sakabe M, Ioka T, Sato GE, Inada K, Iwamoto T, Mori T, Uemura S, et al. Tmem100, an ALK1 receptor signaling-dependent gene essential for arterial endothelium differentiation and vascular morphogenesis. PNAS $2012 \mathbf{1 0 9}$ 12064-12069. (https://doi.org/10.1073/pnas.1207210109)

34 Derynck R \& Zhang YE. Smad-dependent and Smad-independent pathways in TGF- $\beta$ family signalling. Nature 2003425 577-584. (https://doi.org/10.1038/nature02006)

35 Hata A, Lagna G, Massagué J \& Hemmati-Brivanlou A. Smad6 inhibits $\mathrm{BMP} / \mathrm{Smad} 1$ signaling by specifically competing with the Smad4 tumor suppressor. Genes and Development 199812 186-197. (https:// doi.org/10.1101/gad.12.2.186)

36 Wu M, Chen G \& Li YP. TGF- $\beta$ and BMP signaling in osteoblast, skeletal development, and bone formation, homeostasis and disease. Bone Research 20164 16009. (https://doi.org/10.1038/boneres.2016.9)

37 Jadrich JL, O'Connor MB \& Coucouvanis E. The TGF $\beta$ activated kinase TAK1 regulates vascular development in vivo. Development 2006133 1529-1541. (https://doi.org/10.1242/dev.02333)

38 Greenblatt MB, Shim JH \& Glimcher LH. TAK1 mediates BMP signaling in cartilage. Annals of the New York Academy of Sciences 2010 1192 385-390. (https://doi.org/10.1111/j.1749-6632.2009.05222.x)

39 Chen G, Deng C \& Li YP. TGF- $\beta$ and BMP signaling in osteoblast differentiation and bone formation. International Journal of Biological Sciences 20128 272-288. (https://doi.org/10.7150/ijbs.2929)

40 Ohta S, Wang B, Mansour SL \& Schoenwolf GC. BMP regulates regional gene expression in the dorsal otocyst through canonical and non-canonical intracellular pathways. Development 2016143 2228-2237. (https://doi.org/10.1242/dev.137133)
41 Kim TY, Kim W, Smith RE \& Kay EP. Role of p27Kip1 in cAMP- and TGF- $\beta 2$-mediated antiproliferation in rabbit corneal endothelial cells. Investigative Ophthalmology and Visual Science 200142 3142-3149.

42 Graupera M \& Potente M. Regulation of angiogenesis by PI3K signaling networks. Experimental Cell Research 2013319 1348-1355. (https://doi.org/10.1016/j.yexcr.2013.02.021)

43 Graupera M, Guillermet-Guibert J, Foukas LC, Phng LK, Cain RJ, Salpekar A, Pearce W, Meek S, Millan J, Cutillas PR, et al. Angiogenesis selectively requires the $\mathrm{p} 110 \alpha$ isoform of PI3K to control endothelial cell migration. Nature 2008453 662-666. (https://doi.org/10.1038/ nature06892)

44 Manning BD \& Toker A. AKT/PKB signaling: navigating the network. Cell 2017169 381-405. (https://doi.org/10.1016/j.cell.2017.04.001)

45 Saxton RA \& Sabatini DM. MTOR signaling in growth, metabolism, and disease. Cell 2017168 960-976. (https://doi.org/10.1016/j. cell.2017.02.004)

46 Wilhelm K, Happel K, Eelen G, Schoors S, Oellerich MF, Lim R, Zimmermann B, Aspalter IM, Franco CA, Boettger T, et al. FOXO1 couples metabolic activity and growth state in the vascular endothelium. Nature 2016529 216-220. (https://doi.org/10.1038/ nature16498)

47 Oellerich MF \& Potente M. FOXOs and sirtuins in vascular growth, maintenance, and aging. Circulation Research $20121101238-1251$. (https://doi.org/10.1161/CIRCRESAHA.111.246488)

48 Ola R, Dubrac A, Han J, Zhang F, Fang JS, Larrivée B, Lee M, Urarte AA, Kraehling JR, Genet G, et al. PI3K inhibition improves vascular malformations in mouse models of hereditary haemorrhagic telangiectasia. Nature Communications 20167 13650. (https://doi. org/10.1038/ncomms13650)

49 Alsina-Sanchís E, García-Ibáñez Y, Figueiredo AM, Riera-Domingo C, Figueras A, Matias-Guiu X, Casanovas O, Botella LM, Pujana MA, Riera-Mestre A, et al. ALK1 loss results in vascular hyperplasia in mice and humans through PI3K activation. Arteriosclerosis, Thrombosis, and Vascular Biology 201838 1216-1229. (https://doi.org/10.1161/ ATVBAHA.118.310760)

50 Serra H, Chivite I, Angulo-Urarte A, Soler A, Sutherland JD, Arruabarrena-Aristorena A, Ragab A, Lim R, Malumbres M, Fruttiger M, et al. PTEN mediates Notch-dependent stalk cell arrest in angiogenesis. Nature Communications 20156 7935. (https://doi.org/10.1038/ ncomms8935)

51 Roskoski R. ERK1/2 MAP kinases: structure, function, and regulation. Pharmacological Research 201266 105-143. (https://doi.org/10.1016/j. phrs.2012.04.005)

52 Roux PP, Shahbazian D, Vu H, Holz MK, Cohen MS, Taunton J, Sonenberg N \& Blenis J. RAS/ERK signaling promotes site-specific ribosomal protein S6 phosphorylation via RSK and stimulates cap-dependent translation. Journal of Biological Chemistry 2007282 14056-14064. (https://doi.org/10.1074/jbc.M700906200)

53 Araki M, Hisamitsu T, Kinugasa-Katayama Y, Tanaka T, Harada Y, Nakao S, Hanada S, Ishii S, Fujita M, Kawamura T, et al. Serum/ glucocorticoid-regulated kinase 1 as a novel transcriptional target of bone morphogenetic protein-ALK1 receptor signaling in vascular endothelial cells. Angiogenesis 201821 415-423. (https://doi. org/10.1007/s10456-018-9605-x)

54 Medina-Jover F, Gendrau-Sanclemente N \& Viñals F. SGK1 is a signalling hub that controls protein synthesis and proliferation in endothelial cells. FEBS Letters 2020594 3200-3215. (https://doi. org/10.1002/1873-3468.13901)

55 Arencibia JM, Pastor-Flores D, Bauer AF, Schulze JO \& Biondi RM. AGC protein kinases: from structural mechanism of regulation to allosteric drug development for the treatment of human diseases. Biochimica et Biophysica Acta 20131834 1302-1321. (https://doi.org/10.1016/j. bbapap.2013.03.010)

56 Webster MK, Goya L, Ge Y, Maiyar AC \& Firestone GL. Characterization of sgk, a novel member of the serine/threonine protein kinase gene family which is transcriptionally induced by

This work is licensed under a Creative Commons Attribution-NonCommercial 4.0 International License. Licen from Bioscientifica com at 04/26/2023 12:03:15PM 
glucocorticoids and serum. Molecular and Cellular Biology 199313 2031-2040. (https://doi.org/10.1128/mcb.13.4.2031-2040.1993)

57 Brickley DR, Mikosz CA, Hagan CR \& Conzen SD. Ubiquitin modification of serum and glucocorticoid-induced protein kinase-1 (SGK-1). Journal of Biological Chemistry 2002277 43064-43070. (https://doi.org/10.1074/jbc.M207604200)

58 Richter A, Alexdottir MS, Magnus SH, Richter TR, Morikawa M, Zwijsen A \& Valdimarsdottir G. EGFL7 mediates BMP9-induced sprouting angiogenesis of endothelial cells derived from human embryonic stem cells. Stem Cell Reports 201912 1250-1259. (https:// doi.org/10.1016/j.stemcr.2019.04.022)

59 Suzuki Y, Ohga N, Morishita Y, Hida K, Miyazono K \& Watabe T. BMP-9 induces proliferation of multiple types of endothelial cells in vitro and in vivo. Journal of Cell Science 2010123 1684-1692. (https://doi. org/10.1242/jcs.061556)

60 Akla N, Viallard C, Popovic N, Lora Gil C, Sapieha P \& Larrivée B. BMP9 (bone morphogenetic protein-9)/ALK1 (activin-like kinase receptor type I) signaling prevents hyperglycemia-induced vascular permeability. Arteriosclerosis, Thrombosis, and Vascular Biology 201838 1821-1836. (https://doi.org/10.1161/ATVBAHA.118.310733)

61 Muñoz-Félix JM, Cuesta C, Perretta-Tejedor N, Subileau M, LópezHernández FJ, López-Novoa JM \& Martínez-Salgado C. Identification of bone morphogenetic protein 9 (BMP9) as a novel profibrotic factor in vitro. Cellular Signalling 201628 1252-1261. (https://doi. org/10.1016/j.cellsig.2016.05.015)

62 Tang N, Rao S, Ying Y \& Huang Y. New insights into BMP9 signaling in organ fibrosis. European Journal of Pharmacology 2020882173291. (https://doi.org/10.1016/j.ejphar.2020.173291)

63 Catela C, Kratsios P, Hede M, Lang F \& Rosenthal N. Serum and glucocorticoid-inducible kinase 1 (SGK1) is necessary for vascular remodeling during angiogenesis. Developmental Dynamics 2010239 2149-2160. (https://doi.org/10.1002/dvdy.22345)

64 Di Cristofano A. SGK1: the dark side of PI3K signaling. Current Topics in Developmental Biology 2017123 49-71. (https://doi.org/10.1016/ bs.ctdb.2016.11.006)

65 Castel P, Ellis H, Bago R, Toska E, Razavi P, Carmona FJ, Kannan S, Verma CS, Dickler M, Chandarlapaty S, et al. PDK1-SGK1 signaling sustains AKT-independent mTORC1 activation and confers resistance to PI3Ka inhibition. Cancer Cell 201630 229-242. (https://doi. org/10.1016/j.ccell.2016.06.004)

66 Toska E, Castel P, Chhangawala S, Arruabarrena-Aristorena A, Chan C, Hristidis VC, Cocco E, Sallaku M, Xu G, Park J, et al. PI3K inhibition activates SGK1 via a feedback loop to promote chromatin-based regulation of ER-dependent gene expression. Cell Reports 201927 294-306.e5. (https://doi.org/10.1016/j.celrep.2019.02.111)

67 Burchfield JG, Lennard AJ, Narasimhan S, Hughes WE, Wasinger VC, Corthals GL, Okuda T, Kondoh H, Biden TJ \& Schmitz-Peiffer C. Akt mediates insulin-stimulated phosphorylation of Ndrg2: evidence for cross-talk with protein kinase C $\theta$. Journal of Biological Chemistry 2004 279 18623-18632. (https://doi.org/10.1074/jbc.M401504200)

68 Sommer EM, Dry H, Cross D, Guichard S, Davies BR \& Alessi DR. Elevated SGK1 predicts resistance of breast cancer cells to Akt inhibitors. Biochemical Journal 2013452 499-508. (https://doi. org/10.1042/BJ20130342)

69 Falkenberg KD, Rohlenova K, Luo Y \& Carmeliet P. The metabolic engine of endothelial cells. Nature Metabolism 2019 1937-946. (https://doi.org/10.1038/s42255-019-0117-9)

70 Treps L, Conradi LC, Harjes U \& Carmeliet P. Manipulating angiogenesis by targeting endothelial metabolism: hitting the engine rather than the drivers - a new perspective? Pharmacological Reviews 201668 872-887. (https://doi.org/10.1124/pr.116.012492)

71 Zecchin A, Kalucka J, Dubois C \& Carmeliet P. How endothelial cells adapt their metabolism to form vessels in tumors. Frontiers in Immunology 20178 1750. (https://doi.org/10.3389/fimmu.2017.01750)

72 De Bock K, Georgiadou M, Schoors S, Kuchnio A, Wong BW, Cantelmo AR, Quaegebeur A, Ghesquière B, Cauwenberghs S, Eelen G, et al. Role of PFKFB3-driven glycolysis in vessel sprouting. Cell 2013 154 651-663. (https://doi.org/10.1016/j.cell.2013.06.037)

73 Kalucka J, Bierhansl L, Conchinha NV, Missiaen R, Elia I, Brüning U, Scheinok S, Treps L, Cantelmo AR, Dubois C, et al. Quiescent endothelial cells upregulate fatty acid $\beta$-oxidation for vasculoprotection via redox homeostasis. Cell Metabolism 201828 881-894.e13. (https://doi.org/10.1016/j.cmet.2018.07.016)

74 Chen C, Grzegorzewski KJ, Barash S, Zhao Q, Schneider H, Wang Q, Singh M, Pukac L, Bell AC, Duan R, et al. An integrated functional genomics screening program reveals a role for BMP-9 in glucose homeostasis. Nature Biotechnology 200321 294-301. (https://doi. org/10.1038/nbt795)

75 Caperuto LC, Anhê GF, Cambiaghi TD, Akamine EH, do Carmo Buonfiglio D, Cipolla-Neto J, Curi R \& Bordin S. Modulation of bone morphogenetic protein-9 expression and processing by insulin, glucose, and glucocorticoids: possible candidate for hepatic insulinsensitizing substance. Endocrinology 2008149 6326-6335. (https://doi. org/10.1210/en.2008-0655)

76 Jung JW, Yoon SM, Kim S, Jeon YH, Yoon BH, Yang SG, Kim MK, Choe $S$ \& Kuo MM. Bone morphogenetic protein-9 is a potent growth inhibitor of hepatocellular carcinoma and reduces the liver cancer stem cells population. Oncotarget 20167 73754-73768. (https://doi. org/10.18632/oncotarget.12062)

77 Ying Y, Ueta T, Jiang S, Lin H, Wang Y, Vavvas D, Wen R, Chen YG \& Luo Z. Metformin inhibits ALK1-mediated angiogenesis via activation of AMPK. Oncotarget 20178 32794-32806. (https://doi.org/10.18632/ oncotarget.15825)

78 Ben-Sahra I \& Manning BD. mTORC1 signaling and the metabolic control of cell growth. Current Opinion in Cell Biology 201745 72-82. (https://doi.org/10.1016/j.ceb.2017.02.012)

79 Condon KJ \& Sabatini DM. Nutrient regulation of mTORC1 at a glance. Journal of Cell Science 2019132 jcs222570. (https://doi. org/10.1242/jcs.222570)

80 Inoki K, Zhu T \& Guan KL. TSC2 mediates cellular energy response to control cell growth and survival. Cell 2003115 577-590. (https://doi. org/10.1016/s0092-8674(03)00929-2)

81 Shaw RJ, Bardeesy N, Manning BD, Lopez L, Kosmatka M, DePinho RA \& Cantley LC. The LKB1 tumor suppressor negatively regulates mTOR signaling. Cancer Cell 20046 91-99. (https://doi.org/10.1016/j. ccr.2004.06.007)

82 Gwinn DM, Shackelford DB, Egan DF, Mihaylova MM, Mery A, Vasquez DS, Turk BE \& Shaw RJ. AMPK phosphorylation of raptor mediates a metabolic checkpoint. Molecular Cell 200830 214-226. (https://doi.org/10.1016/j.molcel.2008.03.003)

83 Roman BL \& Pekkan K. Mechanotransduction in embryonic vascular development. Biomechanics and Modeling in Mechanobiology 201211 1149-1168. (https://doi.org/10.1007/s10237-012-0412-9)

84 Dekker RJ, Boon RA, Rondaij MG, Kragt A, Volger OL, Elderkamp YW, Meijers JC, Voorberg J, Pannekoek H \& Horrevoets AJ. KLF2 provokes a gene expression pattern that establishes functional quiescent differentiation of the endothelium. Blood $2006 \mathbf{1 0 7} 4354-4363$ (https://doi.org/10.1182/blood-2005-08-3465)

85 Parmar KM, Larman HB, Dai G, Zhang Y, Wang ET, Moorthy SN, Kratz JR, Lin Z, Jain MK, Gimbrone MA, et al. Integration of flowdependent endothelial phenotypes by Kruppel-like factor 2. Journal of Clinical Investigation 2006116 49-58. (https://doi.org/10.1172/ JCI24787)

86 Lehoux S \& Jones EA. Shear stress, arterial identity and atherosclerosis. Thrombosis and Haemostasis 2016115 467-473. (https://doi. org/10.1160/TH15-10-0791)

87 Laux DW, Young S, Donovan JP, Mansfield CJ, Upton PD \& Roman BL. Circulating Bmp10 acts through endothelial Alk1 to mediate flowdependent arterial quiescence. Development $20131403403-3412$. (https://doi.org/10.1242/dev.095307)

88 Zhou J, Lee PL, Tsai CS, Lee CI, Yang TL, Chuang HS, Lin WW, Lin TE, Lim SH, Wei SY, et al. Force-specific activation of Smad1/5 (c) 2022 The authors Published by Bioscientifica Ltd
This work is licensed under a Creative Commons Attribution-NonCommercial 4.0 International License. ded from Bioscientifica com at $04 / 26 / 2023$ 12:03:15PM 
regulates vascular endothelial cell cycle progression in response to disturbed flow. PNAS 2012109 7770-7775. (https://doi.org/10.1073/ pnas.1205476109)

89 Baeyens N, Larrivée B, Ola R, Hayward-Piatkowskyi B, Dubrac A, Huang B, Ross TD, Coon BG, Min E, Tsarfati M, et al. Defective fluid shear stress mechanotransduction mediates hereditary hemorrhagic telangiectasia. Journal of Cell Biology 2016214 807-816. (https://doi. org/10.1083/jcb.201603106)

90 Bernabeu C, Bayrak-Toydemir P, McDonald J \& Letarte M. Potential second-hits in hereditary hemorrhagic telangiectasia. Journal of Clinical Medicine 20209 3571. (https://doi.org/10.3390/jcm9113571)

91 Sugden WW, Meissner R, Aegerter-Wilmsen T, Tsaryk R, Leonard EV, Bussmann J, Hamm MJ, Herzog W, Jin Y, Jakobsson L, et al. Endoglin controls blood vessel diameter through endothelial cell shape changes in response to haemodynamic cues. Nature Cell Biology 201719 653-665. (https://doi.org/10.1038/ncb3528)

92 Tual-Chalot S, Garcia-Collado M, Redgrave RE, Singh E, Davison B, Park C, Lin H, Luli S, Jin Y, Wang Y, et al. Loss of endothelial endoglin promotes high-output heart failure through peripheral arteriovenous shunting driven by VEGF signaling. Circulation Research 2020126 243-257. (https://doi.org/10.1161/CIRCRESAHA.119.315974)

93 Armulik A, Genové G \& Betsholtz C. Pericytes: developmental, physiological, and pathological perspectives, problems, and promises. Developmental Cell 201121 193-215. (https://doi.org/10.1016/j. devcel.2011.07.001)

94 Gaengel K, Genové G, Armulik A \& Betsholtz C. Endothelial-mural cell signaling in vascular development and angiogenesis. Arteriosclerosis, Thrombosis, and Vascular Biology 200929 630-638. (https://doi. org/10.1161/ATVBAHA.107.161521)

95 Figueiredo AM, Villacampa P, Diéguez-Hurtado R, José Lozano J, Kobialka P, Cortazar AR, Martinez-Romero A, Angulo-Urarte A, Franco CA, Claret M, et al. Phosphoinositide 3-kinaseregulated pericyte maturation governs vascular remodeling. Circulation 2020142 688-704. (https://doi.org/10.1161/ CIRCULATIONAHA.119.042354)

96 Teichert M, Milde L, Holm A, Stanicek L, Gengenbacher N, Savant S, Ruckdeschel T, Hasanov Z, Srivastava K, Hu J, et al. Pericyteexpressed Tie2 controls angiogenesis and vessel maturation. Nature Communications 20178 16106. (https://doi.org/10.1038/ ncomms16106)

97 Armulik A, Genové G, Mäe M, Nisancioglu MH, Wallgard E, Niaudet C, He L, Norlin J, Lindblom P, Strittmatter K, et al. Pericytes regulate the blood-brain barrier. Nature 2010468 557-561. (https://doi. org/10.1038/nature09522)

98 Goumans MJ, Valdimarsdottir G, Itoh S, Rosendahl A, Sideras P \& ten Dijke P. Balancing the activation state of the endothelium via two distinct TGF- $\beta$ type I receptors. EMBO Journal 200221 1743-1753. (https://doi.org/10.1093/emboj/21.7.1743)

99 Oh SP, Seki T, Goss KA, Imamura T, Yi Y, Donahoe PK, Li L, Miyazono K, ten Dijke P, Kim S, et al. Activin receptor-like kinase 1 modulates transforming growth factor- $\beta 1$ signaling in the regulation of angiogenesis. PNAS 200097 2626-2631. (https://doi.org/10.1073/ pnas.97.6.2626)

100 Goumans MJ, Valdimarsdottir G, Itoh S, Lebrin F, Larsson J, Mummery C, Karlsson S \& ten Dijke P. Activin receptor-like kinase (ALK) 1 is an antagonistic mediator of lateral TGF $\beta / A L K 5$ signaling. Molecular Cell 200312 817-828. (https://doi.org/10.1016/s10972765(03)00386-1)

101 Jin Y, Kaluza D \& Jakobsson L. VEGF, Notch and TGFß/BMPs in regulation of sprouting angiogenesis and vascular patterning: Table 1. Biochemical Society Transactions 201442 1576-1583. (https://doi org/10.1042/BST20140231)

102 Seki T, Hong KH \& Oh SP. Nonoverlapping expression patterns of ALK1 and ALK5 reveal distinct roles of each receptor in vascular development. Laboratory Investigation 200686 116-129. (https://doi. org/10.1038/labinvest.3700376)
103 Ruiz S, Zhao H, Chandakkar P, Papoin J, Choi H, NomuraKitabayashi A, Patel R, Gillen M, Diao L, Chatterjee PK, et al. Correcting Smad1/5/8, mTOR, and VEGFR2 treats pathology in hereditary hemorrhagic telangiectasia models. Journal of Clinical Investigation 2020130 942-957. (https://doi.org/10.1172/JCI127425)

104 Itoh F, Itoh S, Adachi T, Ichikawa K, Matsumura Y, Takagi T, Festing M, Watanabe T, Weinstein M, Karlsson S, et al. Smad2/Smad3 in endothelium is indispensable for vascular stability via S1PR1 and N-cadherin expressions. Blood 2012119 5320-5328. (https://doi. org/10.1182/blood-2011-12-395772)

105 Rivas V, Carmona R, Muñoz-Chápuli R, Mendiola M, Nogués L, Reglero C, Miguel-Martín M, García-Escudero R, Dorn GW, Hardisson D, et al. Developmental and tumoral vascularization is regulated by $\mathrm{G}$ protein-coupled receptor kinase 2. Journal of Clinical Investigation 2013123 4714-4730. (https://doi.org/10.1172/JCI67333)

106 Rostama B, Turner JE, Seavey GT, Norton CR, Gridley T, Vary CP \& Liaw L. DLL4/Notch1 and BMP9 interdependent signaling induces human endothelial cell quiescence via P27 and thrombospondin-1. Arteriosclerosis, Thrombosis, and Vascular Biology 201535 2626-2637. (https://doi.org/10.1161/ATVBAHA.115.306541)

107 Kontomanolis EN, Kalagasidou S, Pouliliou S, Anthoulaki X, Georgiou N, Papamanolis V \& Fasoulakis ZN. The notch pathway in breast cancer progression. ScientificWorldJournal 201820182415489. (https://doi.org/10.1155/2018/2415489)

108 Benedito R, Roca C, Sörensen I, Adams S, Gossler A, Fruttiger M \& Adams RH. The notch ligands D1l4 and Jagged1 have opposing effects on angiogenesis. Cell 2009137 1124-1135. (https://doi.org/10.1016/j. cell.2009.03.025)

109 Hofmann JJ \& Luisa Iruela-Arispe M. Notch expression patterns in the retina: an eye on receptor-ligand distribution during angiogenesis. Gene Expression Patterns 20077 461-470. (https://doi.org/10.1016/j. modgep.2006.11.002)

110 Murphy PA, Lu G, Shiah S, Bollen AW \& Wang RA. Endothelial Notch signaling is upregulated in human brain arteriovenous malformations and a mouse model of the disease. Laboratory Investigation 200989 971-982. (https://doi.org/10.1038/ labinvest.2009.62)

111 Gale NW, Dominguez MG, Noguera I, Pan L, Hughes V, Valenzuela DM, Murphy AJ, Adams NC, Lin HC, Holash J, et al. Haploinsufficiency of delta-like 4 ligand results in embryonic lethality due to major defects in arterial and vascular development. PNAS 2004 101 15949-15954. (https://doi.org/10.1073/pnas.0407290101)

112 Fang JS, Coon BG, Gillis N, Chen Z, Qiu J, Chittenden TW, Burt JM, Schwartz MA \& Hirschi KK. Shear-induced Notch-Cx37-p27 axis arrests endothelial cell cycle to enable arterial specification. Nature Communications 20178 2149. (https://doi.org/10.1038/s41467-01701742-7)

113 Luo W, Garcia-Gonzalez I, Fernández-Chacón M, Casquero-Garcia V, Sanchez-Muñoz MS, Mühleder S, Garcia-Ortega L, Andrade J, Potente M \& Benedito R. Arterialization requires the timely suppression of cell growth. Nature 2021589 437-441. (https://doi. org/10.1038/s41586-020-3018-x)

114 Larrivée B, Prahst C, Gordon E, del Toro R, Mathivet T, Duarte A, Simons M \& Eichmann A. ALK1 signaling inhibits angiogenesis by cooperating with the Notch pathway. Developmental Cell 201222 489-500. (https://doi.org/10.1016/j.devcel.2012.02.005)

115 Morikawa M, Koinuma D, Tsutsumi S, Vasilaki E, Kanki Y, Heldin CH, Aburatani H \& Miyazono K. ChIP-seq reveals cell type-specific binding patterns of BMP-specific Smads and a novel binding motif. Nucleic Acids Research 201139 8712-8727. (https://doi.org/10.1093/nar/gkr572)

116 Fischer A, Schumacher N, Maier M, Sendtner M \& Gessler M. The Notch target genes Hey1 and Hey2 are required for embryonic vascular development. Genes and Development 200418 901-911. (https://doi. org/10.1101/gad.291004)

117 Villaronga MA, Lavery DN, Bevan CL, Llanos S \& Belandia B. HEY1 Leu94Met gene polymorphism dramatically modifies its biological

This work is licensed under a Creative Commons Attribution-NonCommercial 4.0 International License. ded from Bioscientifica com at $04 / 26 / 2023$ 12:03:15PM 
functions. Oncogene 201029 411-420. (https://doi.org/10.1038/ onc.2009.309)

118 Huang Q, Raya A, DeJesus P, Chao SH, Quon KC, Caldwell JS, Chanda SK, Izpisua-Belmonte JC \& Schultz PG. Identification of p53 regulators by genome-wide functional analysis. PNAS $2004 \mathbf{1 0 1}$ 3456-3461. (https://doi.org/10.1073/pnas.0308562100)

119 Ban J, Bennani-Baiti IM, Kauer M, Schaefer KL, Poremba C, Jug G, Schwentner R, Smrzka O, Muehlbacher K, Aryee DN, et al. EWS-FLI1 suppresses NOTCH-activated p53 in Ewing's sarcoma. Cancer Research 200868 7100-7109. (https://doi.org/10.1158/0008-5472.CAN-076145)

120 Fu YX, Chang A, Chang L, Niessen K, Eapen S, Setiadi A \& Karsan A. Differential regulation of transforming growth factor $\beta$ signaling pathways by notch in human endothelial cells. Journal of Biological Chemistry 2009284 19452-19462. (https://doi.org/10.1074/jbc. M109.011833)

121 Dahlqvist C, Blokzijl A, Chapman G, Falk A, Dannaeus K, Ibâñez CF \& Lendahl U. Functional Notch signaling is required for BMP4-induced inhibition of myogenic differentiation. Development 2003130 6089-6099. (https://doi.org/10.1242/dev.00834)

122 Moya IM, Umans L, Maas E, Pereira PN, Beets K, Francis A, Sents W, Robertson EJ, Mummery CL, Huylebroeck D, et al. Stalk cell phenotype depends on integration of notch and Smad1/5 signaling cascades. Developmental Cell 201222 501-514. (https://doi.org/10.1016/j. devcel.2012.01.007)

123 Cascone I, Napione L, Maniero F, Serini G \& Bussolino F. Stable interaction between $\alpha 5 \beta 1$ integrin and Tie 2 tyrosine kinase receptor regulates endothelial cell response to Ang-1. Journal of Cell Biology 2005 170 993-1004. (https://doi.org/10.1083/jcb.200507082)

124 Carlson TR, Feng Y, Maisonpierre PC, Mrksich M \& Morla AO. Direct cell adhesion to the angiopoietins mediated by integrins. Journal of Biological Chemistry 2001276 26516-26525. (https://doi.org/10.1074/ jbc.M100282200)

125 Weber CC, Cai H, Ehrbar M, Kubota H, Martiny-Baron G, Weber W, Djonov V, Weber E, Mallik AS, Fussenegger M, et al. Effects of protein and gene transfer of the angiopoietin-1 fibrinogen-like receptorbinding domain on endothelial and vessel organization. Journal of Biological Chemistry 2005280 22445-22453. (https://doi.org/10.1074/ jbc.M410367200)

126 Suri C, Jones PF, Patan S, Bartunkova S, Maisonpierre PC, Davis S, Sato TN \& Yancopoulos GD. Requisite role of angiopoietin-1, a ligand for the TIE2 receptor, during embryonic angiogenesis. Cell 199687 1171-1180. (https://doi.org/10.1016/s0092-8674(00)81813-9)

127 Fagiani E \& Christofori G. Angiopoietins in angiogenesis. Cancer Letters 2013328 18-26. (https://doi.org/10.1016/j.canlet.2012.08.018)

128 Zhang J, Fukuhara S, Sako K, Takenouchi T, Kitani H, Kume T, Koh GY $\&$ Mochizuki N. Angiopoietin-1/Tie2 signal augments basal notch signal controlling vascular quiescence by inducing delta-like 4 expression through AKT-mediated activation of $\beta$-catenin. Journal of Biological Chemistry 2011286 8055-8066. (https://doi.org/10.1074/jbc. M110.192641)

129 Brindle NPJ, Saharinen P \& Alitalo K. Signaling and functions of angiopoietin-1 in vascular protection. Circulation Research $2006 \mathbf{9 8}$ 1014-1023. (https://doi.org/10.1161/01.RES.0000218275.54089.12)

130 Jeansson M, Gawlik A, Anderson G, Li C, Kerjaschki D, Henkelman M \& Quaggin SE. Angiopoietin-1 is essential in mouse vasculature during development and in response to injury. Journal of Clinical Investigation 2011121 2278-2289. (https://doi.org/10.1172/JCI46322)

131 Ojeda-Fernandez L, Barrios L, Rodriguez-Barbero A, Recio-Poveda L, Bernabeu C \& Botella LM. Reduced plasma levels of Ang-2 and sEng as novel biomarkers in hereditary hemorrhagic telangiectasia (HHT). Clinica Chimica Acta: International Journal of Clinical Chemistry 2010 411 494-499. (https://doi.org/10.1016/j.cca.2009.12.023)

132 Crist AM, Zhou X, Garai J, Lee AR, Thoele J, Ullmer C, Klein C, Zabaleta J \& Meadows SM. Angiopoietin-2 inhibition rescues arteriovenous malformation in a Smad4 hereditary hemorrhagic telangiectasia mouse model. Circulation 2019139 2049-2063. (https:// doi.org/10.1161/CIRCULATIONAHA.118.036952)

133 Choi EJ, Kim YH, Choe SW, Tak YG, Garrido-Martin EM, Chang M, Lee YJ \& Oh SP. Enhanced responses to angiogenic cues underlie the pathogenesis of hereditary hemorrhagic telangiectasia 2. PLOS ONE 20138 e63138. (https://doi.org/10.1371/journal.pone.0063138)

134 Tual-Chalot S, Oh SP \& Arthur HM. Mouse models of hereditary hemorrhagic telangiectasia: recent advances and future challenges. Frontiers in Genetics 20156 25. (https://doi.org/10.3389/ fgene.2015.00025)

135 Urness LD, Sorensen LK \& Li DY. Arteriovenous malformations in mice lacking activin receptor-like kinase-1. Nature Genetics 200026 328-331. (https://doi.org/10.1038/81634)

136 Mora-Luján JM, Iriarte A, Alba E, Sánchez-Corral MA, Cerdà P, Cruellas F, Ordi Q, Corbella X, Ribas J, Castellote J, et al. Gender differences in hereditary hemorrhagic telangiectasia severity. Orphanet Journal of Rare Diseases 202015 63. (https://doi.org/10.1186/s13023020-1337-5)

137 Sánchez-Martínez R, Iriarte A, Mora-Luján JM, Patier JL, López-Wolf D, Ojeda A, Torralba MA, Juyol MC, Gil R, Añón S, et al. Current HHT genetic overview in Spain and its phenotypic correlation: data from RiHHTa registry. Orphanet Journal of Rare Diseases 202015 138. (https:// doi.org/10.1186/s13023-020-01422-8)

138 Shovlin CL, Guttmacher AE, Buscarini E, Faughnan ME, Hyland RH, Westermann CJ, Kjeldsen AD \& Plauchu H. Diagnostic criteria for hereditary hemorrhagic telangiectasia (Rendu-Osler-Weber syndrome). American Journal of Medical Genetics 200091 66-67. (https://doi.org/10.1002/(sici)1096-8628(20000306)91:1<66::aidajmg12>3.0.co;2-p)

139 McDonald J, Wooderchak-Donahue W, VanSant Webb C, Whitehead K, Stevenson DA \& Bayrak-Toydemir P. Hereditary hemorrhagic telangiectasia: genetics and molecular diagnostics in a new era. Frontiers in Genetics 20156 1. (https://doi.org/10.3389/ fgene.2015.00001)

140 McAllister KA, Grogg KM, Johnson DW, Gallione CJ, Baldwin MA, Jackson CE, Helmbold EA, Markel DS, McKinnon WC \& Murrell J. Endoglin, a TGF- $\beta$ binding protein of endothelial cells, is the gene for hereditary haemorrhagic telangiectasia type 1. Nature Genetics 19948 345-351. (https://doi.org/10.1038/ng1294-345)

141 Gallione CJ, Repetto GM, Legius E, Rustgi AK, Schelley SL, Tejpar S, Mitchell G, Drouin E, Westermann CJ \& Marchuk DA. A combined syndrome of juvenile polyposis and hereditary haemorrhagic telangiectasia associated with mutations in MADH4 (SMAD4). Lancet 2004363 852-859. (https://doi.org/10.1016/S0140-6736(04)15732-2)

142 Wooderchak-Donahue WL, McDonald J, O'Fallon B, Upton PD, Li W, Roman BL, Young S, Plant P, Fülöp GT, Langa C, et al. BMP9 mutations cause a vascular-anomaly syndrome with phenotypic overlap with hereditary hemorrhagic telangiectasia. American Journal of Human Genetics 201393 530-537. (https://doi.org/10.1016/j. ajhg.2013.07.004)

143 Rigelsky CM, Jennings C, Lehtonen R, Minai OA, Eng C \& Aldred MA $B M P R 2$ mutation in a patient with pulmonary arterial hypertension and suspected hereditary hemorrhagic telangiectasia. American Journal of Medical Genetics: Part A 2008 146A 2551-2556. (https://doi. org/10.1002/ajmg.a.32468)

144 Riera-Mestre A, Ribas J \& Castellote J. Medical management of haemorrhagic hereditary telangiectasia in adult patients. Medicina Clinica 2019152 274-280. (https://doi.org/10.1016/j. medcli.2018.09.015)

145 Riera-Mestre A, Cerdà P, Iriarte A, Graupera M \& Viñals F. Translational medicine in hereditary hemorrhagic telangiectasia. European Journal of Internal Medicine 202195 32-37. (https://doi.org/10.1016/j. ejim.2021.09.003)

146 Iriarte A, Figueras A, Cerdà P, Mora JM, Jucglà A, Penín R, Viñals F \& Riera-Mestre A. PI3K (phosphatidylinositol 3-kinase) activation and endothelial cell proliferation in patients with hemorrhagic hereditary

This work is licensed under a Creative Commons Attribution-NonCommercial 4.0 International License. ded from Bioscientifica com at 04/26/2023 12:03:15PM 
telangiectasia type 1. Cells 20198 971. (https://doi.org/10.3390/ cells8090971)

147 Ruiz S, Chandakkar P, Zhao H, Papoin J, Chatterjee PK, Christen E, Metz CN, Blanc L, Campagne F \& Marambaud P. Tacrolimus rescues the signaling and gene expression signature of endothelial ALK1 lossof-function and improves HHT vascular pathology. Human Molecular Genetics 201726 4786-4798. (https://doi.org/10.1093/hmg/ddx358)

148 Ola R, Künzel SH, Zhang F, Genet G, Chakraborty R, Pibouin-Fragner L, Martin K, Sessa W, Dubrac A \& Eichmann A. SMAD4 prevents flow induced arteriovenous malformations by inhibiting casein kinase 2. Circulation 2018138 2379-2394. (https://doi.org/10.1161/ CIRCULATIONAHA.118.033842)

149 Faughnan ME, Gossage JR, Chakinala MM, Oh SP, Kasthuri R, Hughes CCW, McWilliams JP, Parambil JG, Vozoris N, Donaldson J, et al. Pazopanib may reduce bleeding in hereditary hemorrhagic telangiectasia. Angiogenesis 201922 145-155. (https://doi.org/10.1007/ s10456-018-9646-1)

150 Simonds J, Miller F, Mandel J \& Davidson TM. The effect of bevacizumab (Avastin) treatment on epistaxis in hereditary hemorrhagic telangiectasia. Laryngoscope 2009 119 988-992. (https:// doi.org/10.1002/lary.20159)

151 Skaro AI, Marotta PJ \& McAlister VC. Regression of cutaneous and gastrointestinal telangiectasia with sirolimus and aspirin in a patient with hereditary hemorrhagic telangiectasia. Annals of Internal Medicine 2006144 226-227. (https://doi.org/10.7326/0003-4819-144-3200602070-00030)

152 Pavlidis ET \& Pavlidis TE. Role of bevacizumab in colorectal cancer growth and its adverse effects: a review. World Journal of
Gastroenterology 201319 5051-5060. (https://doi.org/10.3748/wjg.v19. i31.5051)

153 Dupuis-Girod S, Ginon I, Saurin JC, Marion D, Guillot E, Decullier E, Roux A, Carette MF, Gilbert-Dussardier B, Hatron PY, et al.

Bevacizumab in patients with hereditary hemorrhagic telangiectasia and severe hepatic vascular malformations and high cardiac output. JAMA 2012307 948-955. (https://doi.org/10.1001/jama.2012.250)

154 Marshall CJ. MAP kinase kinase kinase, MAP kinase kinase and MAP kinase. Current Opinion in Genetics and Development 19944 82-89. (https://doi.org/10.1016/0959-437X(94)90095-7)

155 Bonni A, Ginty DD, Dudek H \& Greenberg ME. Serine 133-phosphorylated CREB induces transcription via a cooperative mechanism that may confer specificity to neurotrophin signals. Molecular and Cellular Neurosciences 19956 168-183. (https://doi. org/10.1006/mcne.1995.1015)

156 Benedito R, Trindade A, Hirashima M, Henrique D, da Costa LL, Rossant J, Gill PS \& Duarte A. Loss of Notch signalling induced by Dll4 causes arterial calibre reduction by increasing endothelial cell response to angiogenic stimuli. BMC Developmental Biology $2008 \mathbf{8} 117$. (https://doi.org/10.1186/1471-213X-8-117)

157 Pollak M. Insulin and insulin-like growth factor signalling in neoplasia. Nature Reviews: Cancer 20088 915-928. (https://doi. org/10.1038/nrc2536)

158 King GL, Kahn CR, Rechler MM \& Nissley SP. Direct demonstration of separate receptors for growth and metabolic activities of insulin and multiplication-stimulating activity (an insulinlike growth factor) using antibodies to the insulin receptor. Journal of Clinical Investigation 198066 130-140. (https://doi.org/10.1172/JCI109826)

Received in final form 21 January 2022

Accepted 7 February 2022

Accepted Manuscript published online 7 February 2022 https://vb.bioscientifica.com

https://doi.org/10.1530/VB-21-0019 (c) 2022 The authors Published by Bioscientifica Ltc

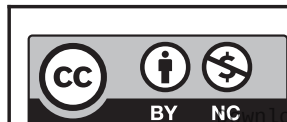

This work is licensed under a Creative Commons Attribution-NonCommercial 4.0 International License.

License. 